\title{
Statement by Jürg Lauber
}

\author{
Permanent Representative of Switzerland to the United Nations
}

\section{(Translation from the French original)}

I have the honour, in my capacity as representative of the host State of the meetings of the International Law Commission, to say a few words to mark this special occasion, the seventieth anniversary of the International Law Commission.

The significance of this day stems, first and foremost, from a simple observation: public international law is central to relations between States and forms the foundation for a stable, just and peaceful international order. As such, the strengthening of public international law is a fundamental element of the Charter of the United Nations and the foreign policy of Switzerland. While this observation held true 70 years ago, it must be acknowledged that it remains highly relevant today, especially in a changing world.

The International Law Commission was established to encourage the progressive development of international law and its codification. Over the past 70 years, the Commission has addressed a wide range of topics such as reservations to treaties, the effects of armed conflict on treaties, the succession of States and governments, jurisdictional immunities of States and their property, and State responsibility, to name just a few. The treatment of these topics and many other topical issues of international law has allowed the Commission to contribute actively to the development and codification of public international law. We await with great interest the outcome of the Commission's work on the topics currently on the agenda, including peremptory norms of international law, crimes against humanity, the protection of the environment in relation to armed conflicts and the immunity of State officials from foreign criminal jurisdiction.

The Committee selects themes that meet criteria such as the needs of States with respect to codification of international law, new trends and pressing concerns of States. In so doing, it ensures that the results of its work are of great value to the international community. These criteria remain fully relevant today.

Switzerland is therefore proud to host the meetings of the International Law Commission in Geneva and, thereby, contribute to its work.

While all efforts to strengthen dialogue between the Sixth Committee of the General Assembly and the International Law Commission are welcome, the 
choice to hold the meetings of the International Law Commission in Geneva ensures notably the complete independence of its work from the Sixth Committee, which is based in New York and whose work is also highly appreciated. We believe that the difference in the legal cultures specific to these two bodies is an asset for the development of international law. In addition, a presence in Geneva enables synergies with over 30 international organizations active in areas that affect everyone's daily lives.

In this connection, and with a view to enhancing the status of the French language, we also consider it important to mention that international law and its development must be promoted not only from United Nations Headquarters in New York, but also from the United Nations Office at Geneva. It will be recalled that the International Law Seminar is held annually in Geneva and allows participants - students, faculty and officials - to learn about the work of the International Law Commission, including through public sessions and lectures given by its members.

Switzerland is pleased to participate in the commemorative events held here in New York, and in Geneva on 5 and 6 July, to mark the vital creation of the International Law Commission, 70 years ago. 